\section{Allometric relationships for predicting the stem volume in a Dalbergia sissoo Roxb. plantation in Bangladesh}

\begin{abstract}
Khan MNI ${ }^{(1-2)}$, Faruque $0^{(2)}$
Allometric relationships for estimating stem volumes of Dalbergia sissoo Roxb. (Sissoo) trees were investigated in monoculture plantations in Bangladesh. The various allometric relationships between stem volume and different dimensions were tested and the coefficient of determination $R^{2}$ values were used to compare the strength of the relationships. Although the allometric equations were highly significant $(P<0.01)$ there was considerable variation among them as indicated by the $\mathrm{R}^{2}$ values. Our results suggested that tree volume is more correlated with basal area than with simple $D$ (stem diameter at $1.3 \mathrm{~m}$ height above the ground). The allometric relationships of stem volume to the tree diameter at $10 \%$ of tree height $\left(D_{0.1}\right)$ did not improve the allometric strength in comparison with simple $D$ as reported in case of some other tree species. The multiplication of tree height $H$ with $D$ in the allometric equation gives a little improvement in the degree of fitness of the allometric equations. However, for the Sissoo plantations studied the stem dbh alone showed a very strong accuracy of estimation $\left(R^{2}=0.997\right)$ especially when used as $D^{2}$. It is concluded that the use of tree height in the allometric equation can be neglected for the species, as far as the present study area is concerned. Therefore, for estimating the stem volume of Sissoo, the use of $D^{2}$ as an independent variable in the allometric equation with a linear or quadratic equation is recommended. The paper describes details of tree volume allometry, which is important in silviculture and forest management.
\end{abstract}

Keywords: Allometry, Monoculture plantation, Regression, Rosewood, Sissoo, Stem volume

\section{Introduction}

Sissoo is known as a premier timber species of the rosewood genus with the common name sissoo in Bangladesh. It is native to Sub-Himalayan zone including India, Pakistan and Afghanistan (Troup 1921, Lodhiyal \& Lodhiyal 2003). It is also recognized as an important species for fuel wood, shade tree, agroforestry and fodder in the region (Troup 1921, Tewari 1994, French \& Blicher 1995). Foresters traditionally derive timber

(1) Department Forest Biometry and Systems Analysis, Institute of Forest Growth and Forest Computer Sciences, TU Dresden, P.O. Box 1117, D-01735 Tharandt (Germany); (2) Forestry and Wood Technology Discipline, Khulna University, 9208 Khulna (Bangladesh)

@ Nabiul Islam Khan (nabiul.khan@forst.tudresden.de)

Received: Mar 04, 2010 - Accepted: Oct 01 , 2010

Citation: Khan MNI, Faruque O, 2010. Allometric relationships for predicting the stem volume in a Dalbergia sissoo Roxb. plantation in Bangladesh. iForest 3: 153-158 [online: 2010-11-15] URL:

http://www.sisef.it/iforest/show.php? id $=554$ volumes by employing allometric techniques. Allometric relationship for estimating stand volume as well as forest biomass is very important for managing any natural and artificial forest resources (Baker et al. 2004, Chave et al. 2005, Malhi et al. 2006, Nogueira et al. 2008). In the estimation of stand volume, the uncertainties appear due to the measurements of basal area and the use of a mean form factor, which is related to mean tapering (Nogueira et al. 2008). Thus, allometric relationships offer better estimates of the forest standing volume, which is also an important parameter in further research such as biomass and carbon-emission estimates avoiding the uncertainties in the bolevolume estimates (Ketterings et al. 2001, Nogueira et al. 2008). Therefore, choosing a suitable functional variable in the allometric equation is very important for allometric techniques in forest science (Ketterings et al. 2001, Khan et al. 2005).

There are various independent variables in the allometric relationships to estimate biomass. In most studies, $D$ (dbh, stem diameter at $1.3 \mathrm{~m}$ height above the ground) was taken as the only independent variable in the allometric equation (e.g., Nakasuga 1979, Putz \& Chan 1986, Clough \& Scott 1989, Am- arasinghe \& Balasubrananiam 1992, Clough et al. 1997, Ong et al. 2004). However, incorporation of the variable $H$ (tree height i.e., the use of $D^{2} H$ ) ensures higher accuracy of allometric estimation in some tree species (Suzuki \& Tagawa 1983, Tamai et al. 1986, Kusmana et al. 1992, Poungparn et al. 2002). Moreover, the use of the new variable $D_{0.1}{ }^{2} H$ $\left(D_{0.1}\right.$, diameter at one-tenth of $\left.H\right)$ instead of $D^{2} H$ has been suggested to improve the accuracy of estimation (Ogawa \& Kira 1977, Hagihara et al. 1993, Khan et al. 2005). Attiwill (1962) found a strong allometric relationship between the girth (at the point immediately before branching) of main branches of a tree and branch dry weight in a stand of Eucalyptus obliqua L' Herit. The use of $D_{\mathrm{B}}$ (stem diameter at a height of clear bole length) provides better results in estimating the weight of branch and leaf, and leaf area per tree, as described by the pipe model theory of Shinozaki et al. (1964). Various allometric equations have been developed from different tropical species (Brown et al. 1989, Overman et al. 1994, Brown 1997, Araújo et al. 1999, Chambers et al. 2001, Ketterings et al. 2001, Chave et al. 2005). It is evident that mainly species of dicotyledonous trees differ in allometry because of distinctive bole shape. The allometric equations developed from various species yield useful estimates for large-scale inventories.

In this paper, we seek to establish the allometric relationships of the stem volume of individual trees to different dimensions, such as $D, D^{2}, D^{2} H, D_{0.1}, D_{0.1}{ }^{2}$ and $D_{0.1}{ }^{2} H$ and to propose a standard method for predicting the stem volume of Sissoo.

\section{Materials and methods}

\section{Study site and species description}

The study was carried out in block plantations at Khulna located in the southern part of Bangladesh (Fig. 1). The area belongs to subtropical region. Dalbergia sissoo is one of the important plantation species in the region.

The species is a strong-light demander and shows good coppicing ability (Troup 1921). The development of seedling is better in full overhead light than under partial shade. It is capable of growing under adverse soil and moisture conditions (Tewari 1994). Though, D. sissoo is a frost hardy species, its young leaves are adversely affected by severe frost and even the poles get completely defoliated (Singh 1963). It has a complex root system that consists of a deep tap root and long lateral roots. Root suckers are produced from the lateral roots. Root suckers develop towards the end of the rainy season and may attain a height of more than $2 \mathrm{~m}$ on good soil 


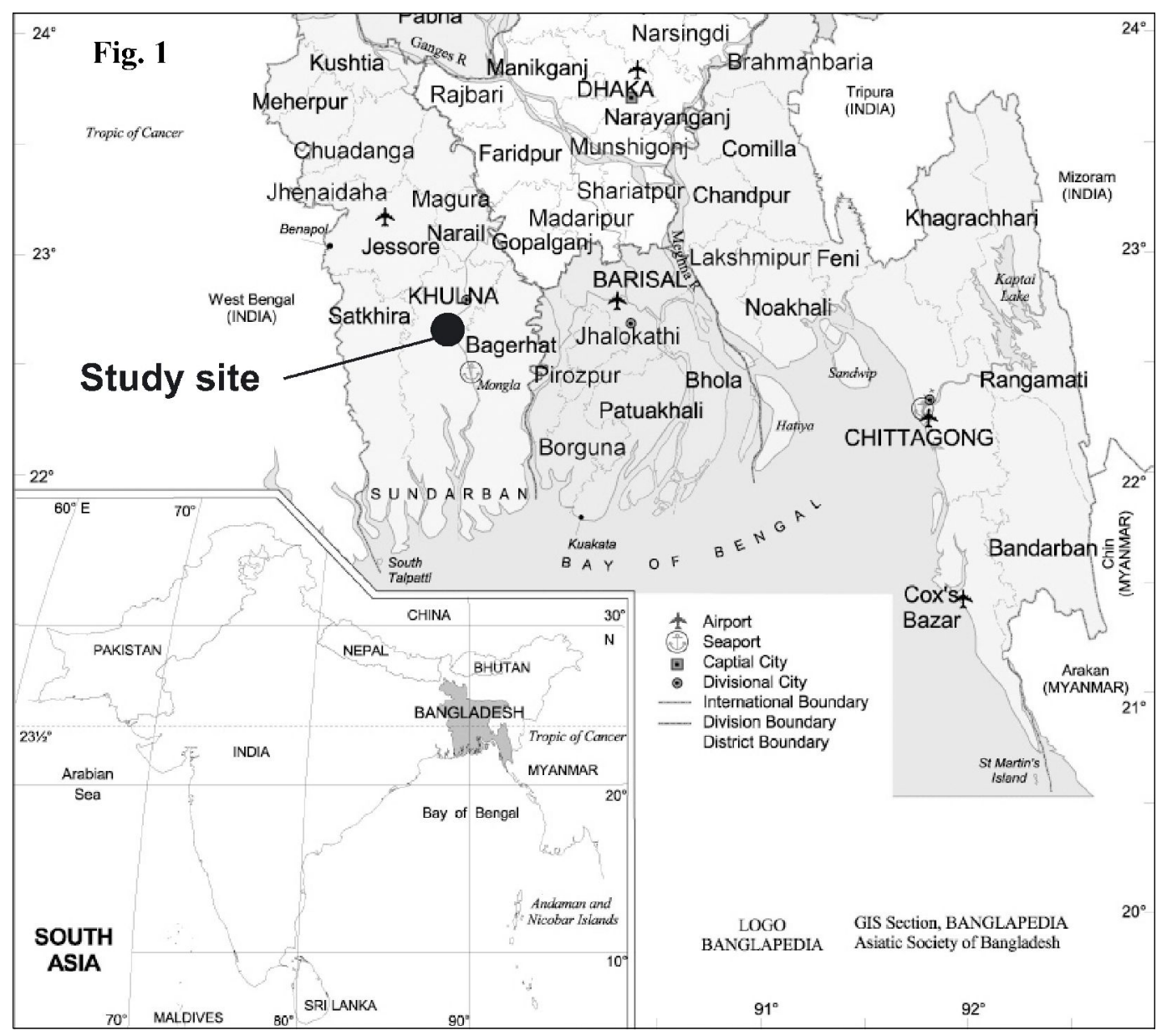

Fig. 1 - Location map of the study site.

(Joshi 1945). The species can grow naturally up to $1500 \mathrm{~m}$ elevation. The temperature in its native range averages $12-22{ }^{\circ} \mathrm{C}$, but varies from just below freezing to nearly $50{ }^{\circ} \mathrm{C}$ with an average annual rainfall of 500 to $2000 \mathrm{~mm}$ with a monsoonal pattern and drought period of 3-4 months (Troup 1921). The growth of the bole is crooked and straight logs of any great length are difficult to obtain. The heartwood is brown with darker streaks and because of its strength and durability, the wood is highly valued for furniture, constructional and general utility purposes.

\section{Sampling, data collection and analysis}

All the studies were carried out in May 2006 in a monoculture plantation of D. sissoo where the canopy was completely closed. A destructive sampling of 30 individual trees with a wide range of diameter and height were used for this study (Tab. 1). The following measurements were carried out: tree height $H$, stem diameter at a height of $H / 10\left(D_{0.1}\right.$ - Khan et al. 2005), stem dbh $D$ and stem diameter at $1.0 \mathrm{~m}$ interval thereafter up to the merchantable height (stem height at $10 \mathrm{~cm}$ diameter). For measuring the diameter, girth values were converted to diameter after divided with $\pi$. Stem volume was calculated using the Smalian's formula (Avery \& Burkhart 1994).

The simple allometric equation is generally written using the power curve (Khan et al. 2005) in the form (eqn. 1):

$$
y=a x^{b}
$$

where $y$ is the dependent variable and $x$ is the independent variable, and $a$ the coefficient and $b$ the allometric constant. The equation is linearized by taking logarithms, as follows (eqn. 2):

$$
\ln (y)=\ln (a)+b \ln (x)
$$

where $\ln a$ and $b$ are the intercept and slope of the regression line, respectively. The $\ln a$ and $b$ are obtained by the method of least squares. In this study, the allometric relationships of the volume and different dimensions such as $D, D^{2}, D^{2} H, D_{0.1}, D_{0.1}{ }^{2}$ and $D_{0.1}{ }^{2} H$ were also established using following equations (eqn. 3 to 7 ):

$$
\begin{array}{ll}
\text { Linear } & y=a+b x \\
\text { Exponential } & y=a+e^{b x} \\
\text { Logarithmic } & y=a+b \log x \\
\text { Quadratic } & y=a+b x+c x^{2} \\
\text { Cubic } & y=a+b x+c x^{2}+d x^{3}
\end{array}
$$

The coefficient of determination $R^{2}$ was calculated using the following equation (based on the real data before logarithmic transformation - eqn. 8):

$$
R^{2}=1-\frac{\sum_{i=1}^{n}\left(y_{i}-\hat{y}_{i}\right)^{2}}{\sum_{i=1}^{n}\left(y_{i}-\bar{y}_{i}\right)^{2}}
$$

where $y_{\mathrm{i}}$ is the observed value, $\hat{y}_{\mathrm{i}}$ is the corresponding values calculated from the regression line, and $\tilde{y}$ is the mean of the observed values (Kvålseth 1985). The $R^{2}$ value (coefficient of determination) is a measure of the goodness-of-fit between the observed and calculated values (Khan et al. 2005).

\section{Results}

Various allometric equations were developed for data fitting. The allometric relationships of stem volume of sissoo trees to $D$ and $D^{2}$ are illustrated in Fig. 2. The scatter plot shows a non-linear trend when $D$ is used as independent variable. This trend is changed to linear distribution if $D^{2}$ is used (Fig. 2). This is also illustrated by the coefficient of determination using $D$, where the power equation $\left(R^{2}=0.970\right)$ shows better fitting than linear equation $\left(R^{2}=0.944\right)$. When $D$ values are squared, the linear equation 
Tab. 1 - Description of sissoo sample trees used for this study. $H$ : Tree height; $D_{0.1}$ : stem diameter at a height of $H / 10 ; D$ : stem diameter at $1.3 \mathrm{~m}$ height (dbh); $V$ : stem volume.

\begin{tabular}{|c|c|c|c|c|c|c|c|c|c|}
\hline Tree No. & D (cm) & $\mathrm{D}_{0.1}(\mathrm{~cm})$ & H (m) & $\mathrm{V}\left(\mathrm{cm}^{3}\right)$ & Tree No. & D (cm) & $D_{0.1}(\mathrm{~cm})$ & H (m) & $\mathrm{V}\left(\mathrm{cm}^{3}\right)$ \\
\hline 1 & 9.549 & 10.027 & 9.01 & 10403.4 & 16 & 13.866 & 14.006 & 10.25 & 36131.8 \\
\hline 2 & 9.708 & 10.504 & 8.01 & 17653.9 & 17 & 14.006 & 14.324 & 8.50 & 60054.8 \\
\hline 3 & 10.134 & 11.141 & 8.02 & 25678.3 & 18 & 14.961 & 14.801 & 14.01 & 89369.7 \\
\hline 4 & 10.663 & 10.982 & 9.01 & 20521.2 & 19 & 15.597 & 15.756 & 14.04 & 101757.4 \\
\hline 5 & 10.759 & 11.459 & 8.07 & 27829.2 & 20 & 16.470 & 16.870 & 14.02 & 128149.9 \\
\hline 6 & 11.141 & 11.937 & 9.03 & 14610.4 & 21 & 16.999 & 17.666 & 11.01 & 139271.9 \\
\hline 7 & 11.513 & 12.414 & 7.50 & 36859.9 & 22 & 17.189 & 17.507 & 10.75 & 122993.6 \\
\hline 8 & 11.678 & 13.051 & 8.02 & 37520.3 & 23 & 21.963 & 22.282 & 12.50 & 206910.6 \\
\hline 9 & 11.937 & 11.937 & 9.57 & 38089.3 & 24 & 26.897 & 26.420 & 15.10 & 411254.8 \\
\hline 10 & 12.321 & 12.573 & 8.50 & 41628.1 & 25 & 27.056 & 26.420 & 15.00 & 390567.9 \\
\hline 11 & 12.614 & 12.892 & 8.50 & 46894.1 & 26 & 27.693 & 27.693 & 14.75 & 437078.1 \\
\hline 12 & 12.984 & 12.796 & 12.01 & 51629.2 & 27 & 29.155 & 28.254 & 20.05 & 569421.1 \\
\hline 13 & 13.210 & 13.528 & 11.03 & 62953.1 & 28 & 31.210 & 29.155 & 20.02 & 665874.1 \\
\hline 14 & 13.242 & 13.210 & 11.02 & 56349.9 & 29 & 32.675 & 30.152 & 20.50 & 759421.1 \\
\hline 15 & 13.687 & 13.433 & 10.25 & 57361.4 & 30 & 33.423 & 31.831 & 21.75 & 819421.1 \\
\hline
\end{tabular}

shows stronger relationship $\left(R^{2}=0.983\right)$ than power equation $\left(R^{2}=0.970\right.$ - Tab. 2$)$. In this case, the polynomial cubic equation showed the best fit for both $D\left(R^{2}=0.997\right)$ and $D^{2}$ $\left(R^{2}=0.996\right)$ with a very close estimate by the quadratic equation for $D\left(R^{2}=0.993\right)$ and $D^{2}\left(R^{2}=0.996\right)$.

Fig. 3 illustrates the allometric relationships of stem volume to $D_{0.1}$ and $D_{0.1}{ }^{2}$. As observed with the variable $D$, the use of $D_{0.1}$ also showed strong data fitting $\left(R^{2}=0.925\right)$ in the allometry (Tab. 2). This relationship is further improved $\left(R^{2}=0.964\right)$ when the $D_{0.1}$ value is squared. The power equation for both the variables $D_{0.1}$ and $D_{0.1}{ }^{2}$ showed the same coefficient of determination $\left(R^{2}=\right.$ $0.961)$. For both the variables $D_{0.1}$ and $D_{0.1}{ }^{2}$ the polynomial cubic and quadratic equations showed a slight stronger fitting (Tab. 2) in comparison with other equations.

As illustrated in Fig. 4, the incorporation of tree height $H$ in the allometric equation gives a better fitting in the linear equation, specially for both $D^{2} H\left(R^{2}=0.995\right)$ and $D_{0.1}{ }^{2} H$ $\left(R^{2}=0.995\right)$. The polynomial cubic along with the quadratic equation showed a very close fit in comparison with the linear equation for both variables $D^{2} H$ and $D_{0.1}{ }^{2} H$ (Tab. 2).

\section{Discussion}

Although the allometric equations were highly significant $(P<0.01)$ there was considerable variation among them as indicated by the coefficient of determination $R^{2}$ values (Tab. 2). The scatter plotting (Fig. 2) shows a non-linear trend for $D$ as independent variable, which becomes linear when plotted against $D^{2}$. This indicates that tree volume is
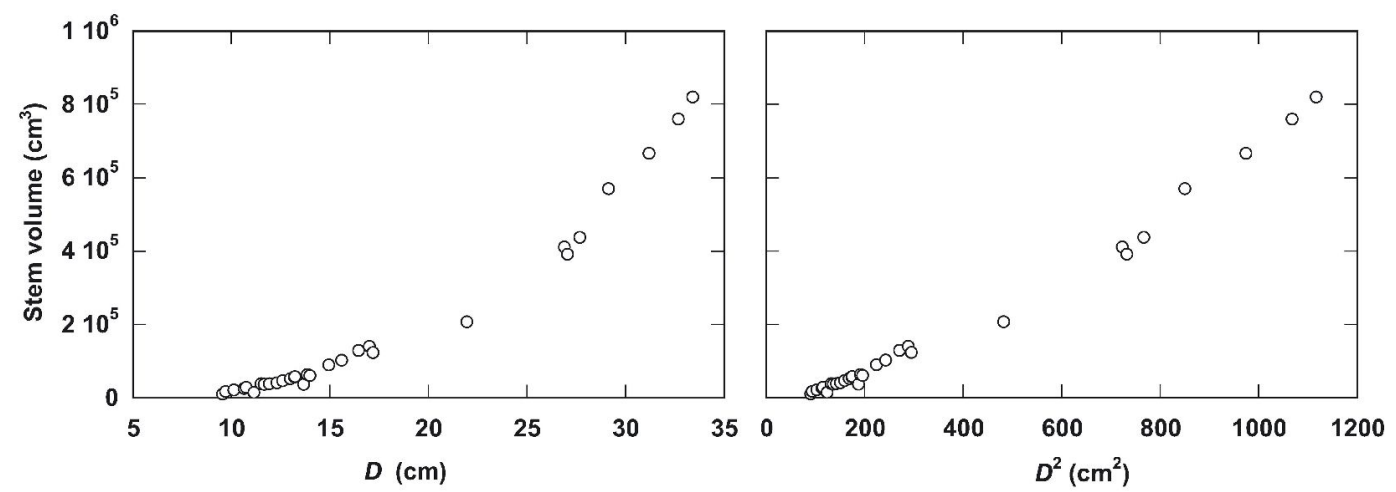

Fig. 2 - Relationships of stem volume to $D$ and $D^{2}$ in $\mathrm{Dal}$ bergia sissoo Roxb. trees.
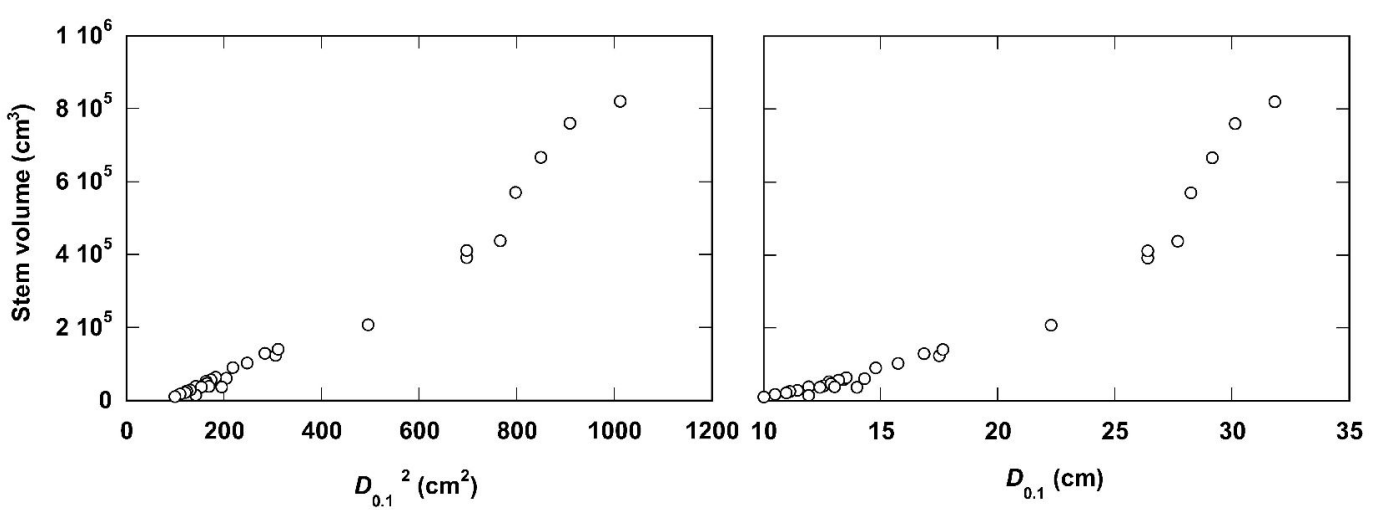

Fig. 3 - Relationships of stem volume to $D_{0.1}$ and $D_{0.1}{ }^{2}$ in Dalbergia sissoo Roxb. trees. 


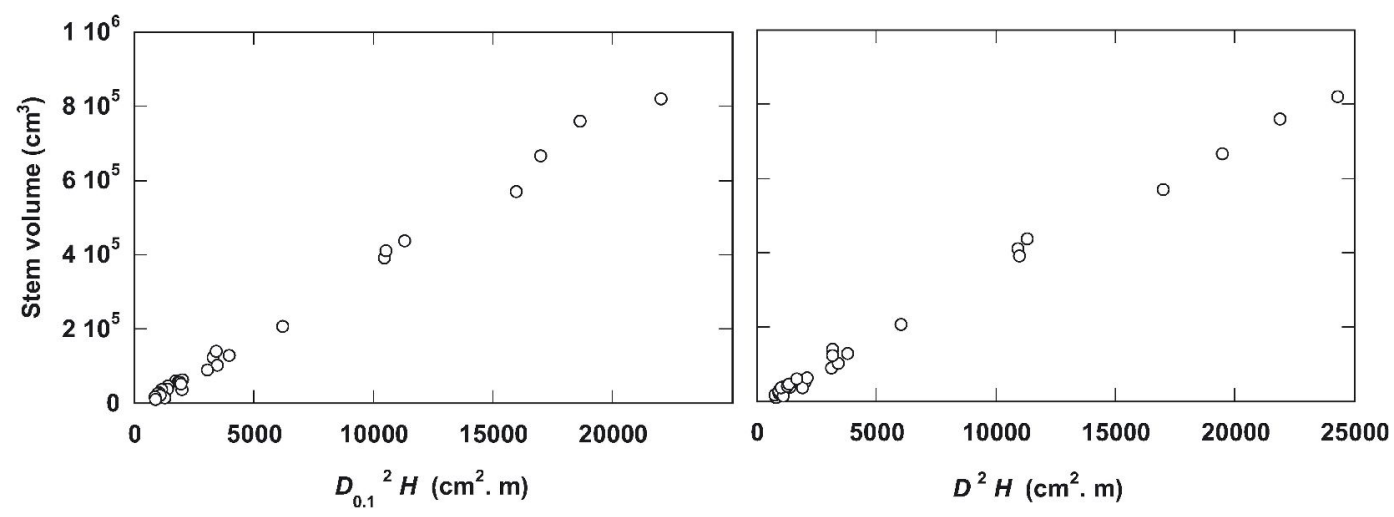

Fig. 4 - Relationships of stem volume to $D^{2} H$ and $D_{0.1}{ }^{2} H$ in Dalbergia sissoo Roxb. trees.

more correlated with basal area than with simple dbh (Burrows et al. 2000). Using the simple $D$ as independent variable in the allometric equation, the cubic equation showed the best fit $\left(R^{2}=0.997\right)$ with a very close estimate by the quadratic equation $\left(R^{2}=\right.$ 0.993). However, there were low differences in the goodness-of-fit among the polynomial, power and linear equations. As the quadratic and cubic equations consist of several coefficients, for practical applications in stand volume estimation, because of simplicity, the linear or power equations the use of $D^{2}$ as an independent variable should be preferred (Khan et al. 2005).

Like the commonly known variable $D$, the use of $D_{0.1}$ also showed strong linear data fitting $\left(R^{2}=0.925\right)$ in the allometry (Tab. 2). This degree of linearity was further improved $\left(R^{2}=0.964\right)$ when $D_{0.1}{ }^{2}$ value is used instead of $D_{0.1}$ (Hagihara et al. 1993, Khan et al. 2005). Here, the cubic equation showed the best fit for both $D_{0.1}\left(R^{2}=0.989\right)$ and $D_{0.1}{ }^{2}\left(R^{2}=0.988\right)$. The next strong fit is also from the quadratic equation for $D_{0.1}\left(R^{2}=\right.$ $0.981)$ and $D_{0.1}{ }^{2}\left(R^{2}=0.987\right)$. Overall, it may be remarked that the allometric relationships of stem volume to the tree diameter at $10 \%$ of tree height $\left(D_{0.1}\right)$ did not improve the allometric strength in D. sissoo in comparison with simple $D$, as reported in case of some tree species (Hagihara et al. 1993, Khan et al. 2005).

The multiplication of tree height $H$ with diameter or basal area in the allometric equation gives high degree of linearity for both the variables $D^{2} H\left(R^{2}=0.995\right)$ and $D_{0.1}{ }^{2} H\left(R^{2}\right.$ $=0.995)$ in the allometric estimation. This suggests that biologically tree diameter and height change proportionality with the change of tree size (Khan et al. 2005). Hence, $H$ is incorporated in the allometric equations, the polynomial cubic and quadratic equations showed a similar degree of fitting in comparison with linear equation for both the variables $D^{2} H$ and $D_{0.1}{ }^{2} H$, because of simplicity, the linear equation would be preferred for indirect estimation in the field with a good level of accuracy $\left(R^{2}=0.995\right)$.
Tab. 2 - Summarized coefficients of the relationships between individual tree volumes of Sissoo to different independent variables. $H$ : Tree height; $D_{0.1}$ : stem diameter at a height of $H / 10 ; D$ : stem diameter at $1.3 \mathrm{~m}$ height $(\mathrm{dbh})$. The units: $\left.D=[\mathrm{cm}], \mathrm{D}_{0.1}=[\mathrm{cm}], H\right]=[\mathrm{m}]$. $\mathrm{LIN}=$ Linear, $\mathrm{LOG}=$ Logarithmic, $\mathrm{QUA}=$ Quadratic, $\mathrm{CUB}=$ Cubic, $\mathrm{POW}=$ Power, $\mathrm{EXP}=$ Exponential.

\begin{tabular}{|c|c|c|c|c|c|c|c|c|}
\hline $\begin{array}{l}\text { Vari- } \\
\text { able }\end{array}$ & $\begin{array}{c}\text { Equa- } \\
\text { tion }\end{array}$ & $\mathbf{a}$ & b & c & d & $\mathbf{R}^{2}$ & $\mathbf{F}$ & Sign. \\
\hline \multirow{6}{*}{ D } & LIN & -342298 & 30629.2 & - & - & 0.944 & 474.4 & $<0.01$ \\
\hline & LOG & $-1 \mathrm{E}+06$ & 561873 & - & - & 0.869 & 186.3 & $<0.01$ \\
\hline & QUA & 145717 & -24827 & 1322.63 & - & 0.993 & 1925.9 & $<0.01$ \\
\hline & CUB & -203182 & 34316.7 & -1754.7 & 49.327 & 0.997 & 2588.8 & $<0.01$ \\
\hline & POW & 15.91 & 3.108 & - & - & 0.97 & 902.6 & $<0.01$ \\
\hline & EXP & 5528 & 0.159 & - & - & 0.928 & 361.7 & $<0.01$ \\
\hline \multirow{6}{*}{$\mathrm{D}^{2}$} & LIN & -75972 & 739.7 & - & - & 0.983 & 1660.3 & $<0.01$ \\
\hline & LOG & $-1 E+06$ & 280937 & - & - & 0.869 & 186.3 & $<0.01$ \\
\hline & QUA & -13315 & 317.6 & 0.3825 & - & 0.996 & 3517 & $<0.01$ \\
\hline & CUB & -31764 & 487.7 & 0.0288 & 0.0002 & 0.996 & 2462.9 & $<0.01$ \\
\hline & POW & 15.91 & 1.554 & - & - & 0.97 & 902.6 & $<0.01$ \\
\hline & EXP & 23664 & 0.0036 & - & - & 0.867 & 182.3 & $<0.01$ \\
\hline \multirow{6}{*}{$\mathrm{D}_{0.1}$} & LIN & -390344 & 33385.1 & - & - & 0.925 & 343 & $<0.01$ \\
\hline & LOG & $-2 \mathrm{E}+06$ & 611406 & - & - & 0.86 & 172.4 & $<0.01$ \\
\hline & QUA & 275457 & -42005 & 1844.01 & - & 0.981 & 696.3 & $<0.01$ \\
\hline & CUB & -445256 & 80012.7 & -4601.5 & 106.354 & 0.989 & 782.3 & $<0.01$ \\
\hline & POW & 7.04 & 3.385 & - & - & 0.961 & 695.9 & $<0.01$ \\
\hline & EXP & 4172 & 0.1752 & - & - & 0.928 & 362.9 & $<0.01$ \\
\hline \multirow{6}{*}{$\mathrm{D}_{0.1}{ }^{2}$} & LIN & -99651 & 828.7 & - & - & 0.964 & 742.6 & $<0.01$ \\
\hline & LOG & $-2 \mathrm{E}+06$ & 305703 & - & - & 0.86 & 172.4 & $<0.01$ \\
\hline & QUA & 7859 & 104.7 & 0.7173 & - & 0.987 & 1043.7 & $<0.01$ \\
\hline & CUB & -30223 & 453.3 & -0.0564 & 0.0005 & 0.988 & 721.3 & $<0.01$ \\
\hline & POW & 7.04 & 1.693 & - & - & 0.961 & 695.9 & $<0.01$ \\
\hline & EXP & 20529 & 0.0042 & - & - & 0.881 & 207.6 & $<0.01$ \\
\hline \multirow{6}{*}{$\mathrm{D}_{2} \mathrm{H}$} & LIN & -5209 & 34.9 & - & - & 0.995 & 5738.1 & $<0.01$ \\
\hline & LOG & $-1 E+06$ & 205386 & - & - & 0.877 & 199 & $<0.01$ \\
\hline & QUA & -15721 & 40.2 & -0.0002 & - & 0.997 & 4000.6 & $<0.01$ \\
\hline & CUB & -17734 & 41.7 & -0.0004 & 4.90E-09 & 0.997 & 2584.4 & $<0.01$ \\
\hline & POW & 11 & 1.125 & - & - & 0.959 & 656.2 & $<0.01$ \\
\hline & EXP & 35224 & 0.0002 & - & - & 0.785 & 102.3 & $<0.01$ \\
\hline \multirow{6}{*}{$\mathrm{D}_{0.1}{ }^{2} \mathrm{H}$} & LIN & -18747 & 39.3 & - & - & 0.995 & 5791.8 & $<0.01$ \\
\hline & LOG & $-2 \mathrm{E}+06$ & 219854 & - & - & 0.877 & 199.2 & $<0.01$ \\
\hline & QUA & -20488 & 40.2 & $-5.00 \mathrm{E}-05$ & - & 0.995 & 2811.9 & $<0.01$ \\
\hline & CUB & -10661 & 33 & 0.0008 & $-3.00 \mathrm{E}-08$ & 0.996 & 1959.7 & $<0.01$ \\
\hline & POW & 5.65 & 1.204 & - & - & 0.959 & 654.2 & $<0.01$ \\
\hline & EXP & 32624 & 0.0002 & - & - & 0.808 & 118.1 & $<0.01$ \\
\hline
\end{tabular}


For predicting timber yield (Madgwick et al. 1991) foresters often combine trunk diameter and height measurements (Madgwick et al. 1991, Avery \& Burkhart 1994) as the independent variables in allometric relationships. However, for the $D$. sissoo plantations studied the stem dbh alone showed a very strong accuracy of estimation $\left(R^{2}=0.983\right.$ to 0.997 ) especially when used as $D^{2}$. Thus, it is concluded that the use of tree height in the allometric equation (Suzuki \& Tagawa 1983, Kusmana et al. 1992, Poungparn et al. 2002, Khan et al. 2005) can be neglected for $D$. sissoo, as far as the present study area is concerned. Therefore, for estimating the stem volume of sissoo, the use of $D^{2}$ as an independent variable in the allometric equation with a linear or quadratic equation is recommended.

The findings of this study indicate that there is a variation in the use of independent variables in allometric equations for estimating the stem volume of the species. The allometric relationships described in this paper may not be appropriate in mixed or open forest stands, because the present study was carried out under monospecific and closed canopy conditions. For estimation stem volume of trees outside the size range of this investigation, care should be taken in extrapolating the present allometric relationships. Therefore, users of these allometric equations are recommended to check some individual trees outside the present size class.

\section{Acknowledgements}

We are grateful to Forestry and Wood Technology Discipline, Khulna University, Bangladesh for providing logistic support for the field data collection. The data analysis and manuscript preparation were performed in the Institute of Forest Growth and Forest Computer Sciences, Technische Universität Dresden, Germany, which was supported by the Alexander von Humboldt Stiftung / Foundation, Germany.

\section{References}

Amarasinghe MD, Balasubrananiam S (1992). Net primary productivity of two mangrove forests stands on the northwest coast of Sri Lanka. Hydrobiologia 247: 37-47. - doi: 10.1007/BF0000 8203

Araújo TM, Higuchi N, Andrade de Carvalho J (1999). Comparison of formulae for biomass content determination in a tropical rain forest site in the state of Pará, Brazil. Forest Ecology and Management 117: 43-52. - doi: 10.1016/S03781127(98)00470-8

Attiwill PM (1962). Estimating branch dry weight and leaf area from measurement of branch girth in Eucalyptus. Forest Science 8: 132-141.

Avery TE, Burkhart HE (1994). Forest Measurements. McGraw- Hill, New York, pp. 408.

Baker TR, Phillips OL, Malhi Y, Almeida S, Arroyo L, Di Fiore A, Killeen TJ, Laurance SG,
Laurance WF, Lewis SL, Lloyd J, Monteagudo A, Neill DA, Patiño S, Pitman NCA, Silva N, Martínez RV (2004). Variation in wood density determines spatial patterns in Amazonian forest biomass. Global Change Biology 10: 45-562. doi: 10.1111/j.1365-2486.2004.00751.x

Brown S (1997). Estimating biomass and biomass change of tropical forests: a primer. FAO Forestry Paper 134, Rome, Italy.

Brown S, Gillespie AJR, Lugo AE (1989). Biomass estimation methods for tropical forests with applications to forest inventory data. Forest Science 35: 881-902.

Burrows WH, Hoffmann MB, Compton JF, Back PV, Tait LJ (2000). Allometric relationships and community biomass estimates for some dominant eucalypts in Central Queensland woodlands. Australian Journal of Botany 48: 707-714. - doi: 10.1071/BT99066

Chambers JQ, dos Santos J, Ribeiro RJ, Higuchi N (2001). Tree damage, allometric relationships, and above-ground net primary production in central Amazon forest. Forest Ecology and Management 152: 73-84. - doi: 10.1016/S03781127(00)00591-0

Chave J, Andalo C, Brown S, Cairns MA, Chambers JQ, Eamus D, Fölster H, Fromard F, Higuchi N, Kira T, Lescure JP, Nelson BW, Ogawa H, Puig H, Riéra B, Yamakura T (2005). Tree allometry and improved estimation of carbon stocks and balance in tropical forests. Oecologia 145: 87-99. - doi: 10.1007/s00442-005-0100-x

Clough BF, Dixon P, Dalhaus O (1997). Allometric relationships for estimating biomass in multistemed mangrove trees. Australian Journal of Botany 45: 1023-1031. - doi: 10.1071/BT96075

Clough BF, Scott K (1989). Allometric relationships for estimating above ground biomass in six mangrove species. Forest Ecology and Management 27: 117-127. - doi: 10.1016/0378-1127(89) 90034-0

French JH, Blicher-Mathiesen U (1995). Introduction to the field sites. In: "International workshop on agroforestry investment, production and marketing". Dehra Dun (India), 17-26 Sept. 1995. APAN Report no. 20, FAO/APAN.

Hagihara A, Yoyota T, Ogawa K (1993). Allometric relations in hinoki (Chamaecyparis obtusa (Sieb. et Zucc.) Endl.) trees. Bulletin of Nagoya University Forestry 12: 11-29.

Joshi KD (1945). Unirrigated canal plantation in the United Provinces. Indian Journal of Forestry 71: 331-335.

Ketterings MQ, Coe R, Noordwijk MV, Amagau Y, Palm AC (2001). Reducing uncertainty in the use of allometric biomass equations for predicting above ground tree biomass in mixed secondary forest. Forest Ecology and Management 146: 199-209. - doi: 10.1016/S0378-1127(00)00460-6 Khan MNI, Suwa R, Hagihara A (2005). Allometric relationships for estimating the aboveground phytomass and leaf area of mangrove Kandelia candal (L.) Druce trees in the Manko Wetland, Okinawa Island, Japan. Trees 19: 266-272. - doi: 10.1007/s00468-004-0377-0

Kusmana C, Sabiham S, Abe K, Watanable H
(1992). An estimation of above ground tree biomass of the mangrove forest in East Sumatra, Indonesia. Tropics 1: 243-257. - doi: 10.3759/tropics. 1.243

Kvålseth TO (1985). Cautionary note about $R^{2}$. American Statistics 39: 279-285. - doi: 10.2307/ 2683704

Lodhiyal N, Lodhiyal SL (2003). Biomass and net primary productivity of Bhabar Shisham forests in central Himalaya, India. Forest Ecology and Management 176: 217-235. - doi: 10.1016/ S0378-1127(02)00267-0

Madgwick HAI, Frederick DJ, Tew DT (1991). Biomass relationships in stands of Eucalyptus species. Bioresource Technology 37: 85-91. doi: 10.1016/0960-8524(91)90115-Z

Malhi Y, Wood D, Baker TR, Wright J, Phillips OL, Cochrane T, Meir P, Chave J, Almeida S, Arroyo L, Higuchi N, Killeen T, Laurance SG, Laurance WF, Lewis SL, Monteagudo A, Neill DA, Vargas PN, Pitman NCA, Quesada CA, Salomão R, Silva JNM, Lezama AT, Terborgh J, Martínez RV, Vinceti B (2006). The regional variation of aboveground live biomass in oldgrowth Amazonian forests. Global Change Biology 12: 1107-1138. - doi: 10.1111/j.13652486.2006.01120.x

Nakasuga T (1979). Analysis of mangrove stands. Japanese Journal of Ecology 24: 237-246 (in Japanese with English summary).

Nogueira EM, Fearnside PM, Nelson BW, Barbosa RI, Keizer EWH (2008). Estimates of forest biomass in the Brazilian Amazon: new allometric equations and adjustments to biomass from wood-volume inventories. Forest Ecology and Management 256: 1853-1867. - doi: 10.1016/j.foreco.2008.07.022

Ogawa H, Kira T (1977). Methods of estimating forest biomass. In: "Primary productivity of Japanese forests" (Shidei T, Kira T eds). Productivity of terrestrial communites, University of Tokyo Press, Tokyo, pp. 15-36.

Ong JE, Gong WK, Wong CH (2004). Allometry and partitioning of the mangrove, Rhizophora apiculata. Forest Ecology and Management 188: 395-408. - doi: 10.1016/j.foreco.2003.08.002

Overman JPM, Witte HJL, Saldarriaga JG (1994). Evaluation of regression models for aboveground biomass determination in Amazon rainforest. Journal of Tropical Ecology 10: 207-218. - doi: 10.1017/S0266467400007859

Poungparn S, Komiyama A, Patanaponpaipoon P, Jintana V, Sangatiean T, Tanapermpool P, Piriyayota S, Maknual C, Kato S (2002). Site independent allometric relationships for estimating above-ground weights of mangroves. Tropics 12: 147-158. - doi: 10.3759/tropics. 12.147

Putz FE, Chan HT (1986). Tree growth, dynamic, and productivity in a mature mangrove forest in Malaysia. Forest Ecology and Management 17: 211-230. - doi: 10.1016/0378-1127(86)90113-1 Shinozaki K, Yoda K, Hozumi K, Khira T (1964). A quantitative analysis of plant form-the species model theory. II. Further evidence of the theory and its application in forest ecology. Japanese Journal of Ecology 14: 133-139. 
Singh B (1963). First irrigated plantation of Rajasthan. Indian Journal of Forestry 89: 690-700.

Suzuki E, Tagawa H (1983). Biomass of mangrove forest and a sedge marsh on Ishigaki island, south Japan. Japanese Journal of Ecology 33: $231-234$
Tamai S, Nakasuga T, Tabuchi R, Ogino K (1986). Standing biomass of mangrove forests in southern Thailand. Journal of Japanese Forestry Society 68 : 384-388.

Tewari DN (1994). A monograph on Dalbergia sissoo Roxb. Indian Council on Forestry Re- source and Education, International Books Distributors, Deharadun, India.

Troup RS (1921). The silviculture of Indian trees 1. Oxford University Press, Oxford, United Kingdom. 